\section{Shade availability on pasture does not affect semen characteristics of Brahman bulls (Bos taurus indicus)}

\author{
Presença de sombra a pasto não afeta as características \\ espermáticas de touros da raça Brahman (Bos taurus indicus)
}

Paulo Fantinato Neto ${ }^{*}$ (D), Ana Carina Alves Pereira de Mira Geraldo² (D),

Thais Mayra da Cunha Leme dos Santos ${ }^{3}$ (D) , Reíssa Alves Vilela ${ }^{3}$, Adriana Moraes de Oliveira Tribucci André Furugen Cesar de Andrade ${ }^{4}$ (D) , Rubens Paes Arruda ${ }^{5}$ (I) \& Evado Antonio Lencioni Titto ${ }^{6}$ (i)

Veterinarian, Departamento de Zootecnia (ZAZ), Faculdade de Zootecnia e Engenharia de Alimentos (FZEA), Universidade de São Paulo (USP). Campus "Fernando Costa", Pirassununga, SP, Brazil.

'Zootechnist, MSc., ZAZ, FZEA, USP. Campus "Fernando Costa", Pirassununga, SP, Brazil.

3Zootechnist, ZAZ, FZEA, USP. Campus "Fernando Costa", Pirassununga, SP, Brazil.

"Veterinarian, Departamento de Reprodução Animal (VRA), Faculdade de Medicina Veterinária e Zootecnia (FMVZ), USP Campus "Fernando Costa", Pirassununga, SP, Brazil.

5Veterinarian, DSC., VRA, FMVZ, USP. Campus "Fernando Costa", Pirassununga, SP, Brazil.

${ }^{V}$ Veterinarian, DSc., ZAZ, FZEA, USP. Campus "Fernando Costa", Pirassununga, SP, Brazil.

\begin{abstract}
Testicular degeneration by heat is the leading cause of infertility in bulls. Beef cattle are generally farmed under hot and humid conditions, and consequently, the thermotolerance of each breed must be considered in their natural environment. This study aimed to evaluate the reproductive characteristics of Brahman bulls maintained in the grazing system, with or without shadow availability. Ten Brahman bulls aging between 24 and 30 months were allocated in two different paddocks, with or without shadow availability. The heat tolerance test was performed on three non-consecutive typical summer days. The semen samples were collected at four times points in a 14 days interval. The climate conditions were monitored throughout the experiment; and clinical evaluation, testicular consistence and scrotal circumference were measured before every semen collection. In addition, semen was evaluated regarding volume, aspect, turbulence, motility, straight movement, sperm concentration, and morphological exam. The studied Brahman bulls showed a high thermolysis capacity, high heat tolerance, and no differences in semen quality were observed between groups.
\end{abstract}

Keywords: environment, heat stress, thermotolerance, breeding soundness evaluation, zebu.

\section{RESUMO}

A degeneração testicular causada pelo calor é a principal causa de infertilidade em touros. Bovinos de corte geralmente são criados em condições de calor e umidade, e, consequentemente, a termotolerância de cada raça deve ser considerada em seu ambiente natural. O presente trabalho teve como objetivo avaliar as características reprodutivas de touros da raça Brahman mantidos em sistema de pastejo, com ou sem disponibilidade de sombra. Dez touros Brahman com idades entre 24 e 30 meses foram alocados em dois piquetes diferentes, com ou sem disponibilidade de sombra. O teste de tolerância ao calor foi realizado em três dias típicos de verão não consecutivos. As amostras de sêmen foram coletadas em quatro momentos em intervalos de 14 dias. As condições climáticas foram monitoradas durante todo o período experimental; e a avaliação clínica, consistência testicular e a circunferência escrotal foram avaliadas antes de cada coleta de sêmen. Ainda, o sêmen foi avaliado quanto ao volume, aspecto, turbulência, motilidade, vigor, concentração espermática e exame morfológico. Os touros estudados da raça Brahmman apresentaram alta capacidade de termólise, alta tolerância ao calor, e não foram observadas diferenças na qualidade do sêmen entre os grupos.

Palavras-chave: ambiente, estresse por calor, termotolerância, avaliação reprodutiva, zebu.

\section{B] $\mathbf{M}$ \\ Brazilian Journal of Veterinary Medicine \\ p-ISSN 0100-2430 \\ e-ISSN 2527-2179 \\ ఠ}

How to cite: Fantinato Neto, P., Geraldo, A. C. A. P. M., Santos, T. M. C. L., Vilela, R. A., Tribucci, A. M. O., Andrade, A. F. C., Arruda, R. P., \& Titto, E. A. L. (2021). Shade availability on pasture does not affect semen characteristics of Brahman bulls (Bos taurus indicus). Brazilian Journal of Veterinary Medicine, 43, e003721. https://doi. org/10.29374/2527-2179.bjvm003721

Received: September 21, 2021. Accepted: November 03, 2021

\section{*Correspondence}

Paulo Fantinato Neto

Departamento de Medicina Veterinária ZMV, Faculdade de Zootecnia e Engenharia de Alimentos - FZEA, Universidade de São Paulo - USP

Av. Duque de Caxias Norte, 225, Campus

"Fernando Costa"

CEP 13635-900 - Pirassununga (SP), Brasil

E-mail: fantinato@usp.br 


\section{Introduction}

In mammals, the testicular temperature is maintained between 4 and $6^{\circ} \mathrm{Cbelow}$ body temperature, an important mechanism required for proper spermatogenesis and sperm storage, avoiding apoptosis, DNA damage, and disrupted gene expression in gametes (Durairajanayagam et al., 2015; Kastelic, 2014; Li et al., 2020; Newton et al., 2009; Rahman et al., 2011), which can lead to low fertility rates or even undesired phenotypes in the newborn offspring (Wan et al., 2020a, 2020b).

The physiological consequences of heat stress in males are often studied by increasing testicular temperature, which is usually induced artificially, for example, by scrotal bags or insulation (GarciaOliveros et al., 2020; Newton et al., 2009; Rahman et al., 2011) or using hot rooms or heating semen (Peña Junior et al., 2021); hence, naturally high environmental temperatures have also been shown to disrupt the male reproductive physiology in the different species (Li et al., 2020; Rasooli et al., 2010; Seifi-Jamadi et al., 2020). Once heat stress in animals leading to reproductive failure may occur when high environmental temperatures can no longer be adjusted by the body and its compensatory physiological mechanisms (Kastelic et al., 1997), the in situ studies of the process may lead to more robust and physiological outcomes and insights on which the environment itself influences parameters.

It has been shown and discussed that different heat stress conditions (for example, induced or natural exposure, as well as mild or severe stress) may lead to different outcomes; for example, mild and moderate heat stress may show adverse effects on sperm and fertility in mice and farm animals more susceptible to high temperatures (Rizzoto et al., 2020; Seifi-Jamadi et al., 2020); whereas the called "adapted" animals in hot and humid climates may not exhibit any difference in sperm evaluation of fertility throughout the year (reviewed in Morrell, 2020; Rasooli et al., 2010).

Cattle are an important farmed source for meat and dairy products worldwide, and the features related to adaptation and response to the environment are essential to optimize production. Therefore, breed differences, in special regarding ability (beef x milk), and farming systems (housed $x$ grass based) are essential figures to be mainly analyzed for each herd and purpose.

Particularly in tropical countries, beef cattle usually outnumber dairy herds due mainly to environmental conditions, for example, in Brazil, once the breeding conditions can reach $35^{\circ} \mathrm{C}$ air temperature, the black globe temperature (BGT) may reach $50{ }^{\circ} \mathrm{C}$ (Titto et al., 2011), and breeding is mainly performed in grassland-based systems, where natural or artificial shadows are alternatives for decreasing solar radiation, thus leading to thermal comfort and favoring homeothermy (Her et al., 1988; Muller et al., 1994; Tucker et al., 2008). Several studies have already reported the heat tolerance in the Nelore breed (McManus et al., 2009; Ribeiro et al., 2010; Titto et al., 1998), including the association between heat tolerance and male reproductive characteristics (Nichi et al., 2006; Pastore et al., 2008).

In this context, the Brahman breed is particularly interesting because even though its strengths rely on productivity, meat quality, precocity, and fertility; and therefore, it is considered a beef cattle, it also presents maternal ability and early history and studies on milk yield (Brown \& Brown Junior, 2002; Neidhardt et al., 1979). Furthermore, although some studies have reported the Brahman bull's heat tolerance in general (Façanha et al., 2019; Hammond et al., 1996; Krininger III et al., 2003; Tatman et al., 2004), mostly related to F1 crossbreed animals, few studies associate sperm quality with differences in heat tolerance related to seasonal variance (Boe-Hansen et al., 2020; Chacón et al., 2002; Godfrey et al., 1990). Hence, we hypothesize that Brahman bulls is well adapted to tropical environments, has great heat tolerance and shadow availability does not interfere in breeding soundness.

\section{Materials and methods}

All procedures were performed following the rules issued by the National Council for Control of Animal Experimentation (CONCEA), following the ARRIVE guidelines, and was approved by the Ethics Committee on Animal Experimentation of the Faculty of Animal Science and Food Engineering, University of São Paulo (Protocol \#4400100621).

\section{Climate, animals, and experimental design}

The experiment was conducted at 21057'05"S and 47037'26"W and 648m above sea level in Descalvado, São Paulo, Brazil. The regional climate is classified as the Cwa of Köppen and the study were conducted in summer, between January and March. Air temperature and humidity, and BGT were monitored daily. Measurements were performed at sunrise, halfway through the 
morning, midday, halfway through the afternoon, and at sunset. In the days the tolerance tests were measured, the climate variables were also monitored every time the animals were managed beyond the time points outlined above. The Black Globe and Humidity Index (BGHI) and the Temperature and Humidity Index (THI) were calculated and used to evaluate heat stress.

Ten Brahman bulls aged between 24 and 30 months were examined three times prior to experimentation regarding the motility and morphology (major and minor defects) of the semen using the formula: "ANIMAL CLASSIFICATION $=(3 \mathrm{x} M T B D)+(2 \mathrm{x} M T S D)+(1 \mathrm{xMiM})$ ", where $M T B D$ is the mean of total major defects, MTSD is the mean of total minor defects, and MiMis the mean of the inverse of motility. Thus, the boars were assigned blocked by quality semen in one of the two treatment groups, as follows: $\mathrm{S}=$ with available artificial shadow $(n=5)$ and NS= unavailable shadow $(n=5)$. The artificial shade was produced by a $100 \mathrm{~m}^{2}$ polyethylene cover, which means that there were approximately $20 \mathrm{~m}^{2}$ of shade for each bull.

Three samples were collected each week prior to the experimental period, and four samples were collected every 14 days to evaluate the effects of environmental temperature on reproductive characteristics.

\section{Breeding soundness examination}

\section{General physical and genital clinical examination}

Before each semen collection, a clinical reproductive examination was performed to evaluate the bulls' general condition and to examine the reproductive organs. The scrotal skin was evaluated for injuries, presence of parasites, and differences among animals; testicular mobility was evaluated to discard any prior damage; testicular consistency was scored from 1 to 5 , where 1 is soft, and 5 is firm; scrotal circumference was evaluated to monitor its progress during the study, and annexed glands by rectal palpation were examined to evaluate morphological variations. The penis was clinically evaluated in all animals during exposure caused by electroejaculation.

\section{Semen collection and spermiogram}

Electroejaculation was accomplished using a manually controlled electroejaculator (DUBOI, Campo Grande, MS, Brazil) and a $70 \mathrm{~mm}$ diameter rectal probe enclosing three ventrally oriented electrodes. All electroejaculation procedures were performed by trained and experienced operators. Plastic cones were attached to $15 \mathrm{ml}$ plastic tubes (Becton, Dickinson and Company, NJ, USA) to recover the semen. To prevent chilling of the sample, the tube was maintained in a water bath at $36^{\circ} \mathrm{C}$; the tube was allocated into an insulator to maintain its temperature at the moment of the collection. Subsequently, semen was carried to the laboratory, where analyses of raw semen were carried out, and subsamples were set aside for further collection analyses (concentration and morphological exams).

The volume and appearance of the semen were evaluated macroscopically. Semen analyses were performed using phase-contrast microscopy (Winkel phase, Carl Zeiss, Germany), where gross motility, progressive motility, and major, minor and total defects were evaluated. The gross motility was assessed under 100x magnification on a warmed microscope slide. The progressive motility was determined under 100x magnification after placing a coverslip over a 2-4 mm drop of semen on a warmed microscope slide, concentration was evaluated using a hemacytometer (Optik Labor, Lancing, United Kingdom). To assess sperm morphology, the samples were diluted and fixed in pre-warmed $\left(37^{\circ} \mathrm{C}\right)$ formaldehyde-PBS. Sperm cells $(n=200)$ were counted under contrast microscopy (Winkel phase, Carl Zeiss, Germany) at a magnification of 1000×. Sperm alterations were classified according to Blom (1973) and Barth \& Oko (1989) into major defects (e.g., acrosome defects, proximal droplets, and abnormal loose heads) and minor defects (e.g., small normal heads, normal loose heads, and abaxial implantation).

\section{Heat tolerance test}

The Heat Tolerance Test was performed during three non-consecutive sunny days, without or with minimum wind or clouds, as described by E. A. L. Titto et al. (1998) and C. G. Titto et al. (2011). The test was performed during the warmest hours of the day (from 11:00 AM to 03:30 PM), and the bulls had no access to food or water during the test. For the test, the bulls were transferred to a shadowed pen for two hours (from 11hOO AM to $13 \mathrm{hOO} \mathrm{PM}$ ); at the end of these 2 hours, 
we measured the first temperatures (T1) of the animals. The animals were then confined to a pen without shade for one hour (from O1h15 PM to 02h15 PM) and then returned to a pen with shade for another hour (from 02h15 PM to 03h15 PM), at which point, we measured the second temperatures (T2) of the bulls. The temperatures of the bulls were used in the formula: IHTI = 10 - (T2-T1), whereas IHTI is the Individual Heat Tolerance Index. An IHTI score closer to 10 indicates a bull that is more efficient at losing heat, thus more tolerant to heat stress.

\section{Statistical analysis}

The data obtained from experimental procedures were analyzed by the Statistical Analysis System program (SAS Institute, 1995). Data from the semen analyses were submitted to analyses of normality of residues using the Shapiro-Wilk test, and variance was compared using the Bartlett's test. The data that did not meet the statistical premises were submitted to logarithm transformation $[\log (\mathrm{X}+1)]$. The original or transformed data, when necessary, were analyzed using analysis of variance. Data that were collected over multiple time points were analyzed using a repeated measures test. The probability of an interaction with time was determined by the Greenhouse-Geisser test, using the command REPEATED generated by proceeding - GLM. The experimental model that was used was as follows: $Y=\mu+\operatorname{Tr}_{i}+T_{f}+\left(\operatorname{Tr}_{i} T_{\rho}\right)_{i f}+B_{j}+e_{i j}$, where $Y$ is the observation of treatments $i$ and $f$ in block $j, \mu$ is the general mean, $\operatorname{Tr}_{i}$ is the effect of treatment $i$, $T_{f}$ is the effect of time $f_{,}\left(\operatorname{Tr}_{i} T_{\rho}\right)_{i f}$ is the effect of the interaction between the treatment $i$ and time $f_{\text {, }}$ $B_{j}$ is the effect of the block $j$ formed in the function of an index determined for each animal, and

$e_{i j}$ is the unexplained error. The heat tolerance data were analyzed using the analysis of variance and Duncan tests. The Heat Tolerance Test (HTT) and the heat tolerance indexes were analyzed using the REPEATED statement of PROC MIXED (SAS Institute, 1995), where the HTT data collected each day is a repeated measurement in time. The correlation between semen defects and IHTI was determined by proceeding CORR; in all the statistical analyses, the significance level was considered to be $5 \%$.

\section{Results}

\section{Climatic data}

During the experimental period, the environmental temperatures were maximum of $34.2^{\circ} \mathrm{C}$, minimum of $15.5^{\circ} \mathrm{C}$, with an average of $25^{\circ} \mathrm{C}$. The relative humidity ranged between $55 \%$ and $98 \%$, with an average of $76.9 \%$. The black globe average temperatures at the non-shaded and shaded sites were $49^{\circ} \mathrm{C}$ e $34.8^{\circ} \mathrm{C}$, respectively. Therefore, black globe temperatures at the non-shaded site had a minimum temperature of $45^{\circ} \mathrm{C}$; thus, the minimum BGHI calculated was 95.7. We also calculated the THI to compare with BGHI in terms of heat tolerance. The climatic data are summarized in Table 1 and analyze groups through time regarding average air temperature and black globes temperatures.

Table1. Climatic data during the experimental days and nights. Dry bulb and black globe temperatures, relativity humidity, Black Globe and Humidity Index (BGHI), and Temperature and Humidity Index (THI).

\begin{tabular}{cccc}
\hline Variable & Mean \pm SD & Maximum & Minimum \\
\hline Temperature, ${ }^{\circ} \mathrm{C}$ & & & \\
Ambient & $25.1 \pm 2.0$ & 34.2 & 15.5 \\
Black globe & $48.6 \pm 1.6$ & 50.0 & 46.0 \\
Relative humidity, $\%$ & $85.4 \pm 2.3$ & 98.0 & 55.0 \\
THI,$~^{\circ} \mathrm{C}$ & $73.5 \pm 2.7$ & 77.6 & 70.1 \\
BGHI, ${ }^{\circ} \mathrm{C}$ & $97.5 \pm 2.2$ & 100.9 & 94.6 \\
\hline
\end{tabular}




\section{Breeding soundness examination}

A clinical examination of all animals prior to semen collection showed no diseases during the experimental period. The scrotal skin and accessory gland examinations, volume and aspect of the collected semen revealed no differences throughout time nor between groups. No differences were observed in scrotal circumference or testicular consistency during the experimental period ( $p>0.05$ ). The average, maximum and minimum values observed for scrotal circumference were 33.9, 39.0, and $30.0 \mathrm{~cm}$ for bulls in the paddock with shade and 34.53, 39.0, and 31.0 for bulls without shade availability. In the group with shade, the average, maximum and minimum values of testicular consistency were 2.7, 3.5, and 2.0, respectively, whereas, in the other group, the average, maximum and minimum values were 3.4, 4.0, and 2.0, respectively. Gross motility, progressive motility, and vigor had no significance differences ( $p>0.05$ ) between the treatment and the collection time. The main abnormalities found were detached heads, coiled tails, and knobbed acrosomes for the groups with and without shadow availability. No differences were observed between groups nor collection time ( $p>0.05$ ), and results are summarized in Table 2.

Table 2. Means (SD) of motility, turbulence, vigor, and sperm morphology for the groups with availability of shade (S) or no shade (NS) in the 4 collection times (14 days apart).

\begin{tabular}{|c|c|c|c|c|c|c|c|}
\hline \multirow{2}{*}{$\begin{array}{l}\text { Sample } \\
\text { collection }\end{array}$} & \multirow[b]{2}{*}{ Group } & \multicolumn{6}{|c|}{ Semen characteristic } \\
\hline & & $\begin{array}{l}\text { Progressive } \\
\text { Motility }^{1}\end{array}$ & $\begin{array}{c}\text { Gross } \\
\text { Motility }^{2}\end{array}$ & $\begin{array}{c}\text { Straight } \\
\text { movement }^{3}\end{array}$ & $\begin{array}{c}\text { Major } \\
\text { Defects }^{4}\end{array}$ & $\begin{array}{c}\text { Minor } \\
\text { Defects }^{5}\end{array}$ & $\begin{array}{c}\text { Total } \\
\text { Defects }^{6}\end{array}$ \\
\hline \multirow[t]{4}{*}{1} & S & 65.00 & 3.90 & 3.30 & 14.00 & 11.80 & 25.80 \\
\hline & & (24.24) & (1.14) & $(0.76)$ & (10.65) & (5.85) & (12.44) \\
\hline & NS & 47.00 & 3.30 & 3.10 & 22.40 & 7.60 & 30.00 \\
\hline & & $(28.64)$ & (1.30) & $(0.22)$ & (8.65) & (8.14) & (11.31) \\
\hline \multirow[t]{4}{*}{2} & S & 61.00 & 3.50 & 3.30 & 14.40 & 7.60 & 22.00 \\
\hline & & (15.17) & $(0.94)$ & $(0.45)$ & (11.15) & (2.33) & $(9.77)$ \\
\hline & NS & 46.00 & 2.70 & 2.20 & 10.00 & 8.60 & 18.60 \\
\hline & & (25.35) & (1.79) & $(0.45)$ & (6.33) & $(4.10)$ & (9.02) \\
\hline \multirow[t]{4}{*}{3} & S & 63.00 & 3.60 & 3.10 & 13.50 & 10.00 & 23.50 \\
\hline & & (23.35) & $(0.82)$ & $(0.74)$ & (5.81) & (3.66) & $(6.51)$ \\
\hline & NS & 45.00 & 4.40 & 2.80 & 11.13 & 7.25 & 18.38 \\
\hline & & (24.49) & $(0.65)$ & $(1.04)$ & (2.46) & (5.38) & $(5.76)$ \\
\hline \multirow[t]{4}{*}{4} & S & 53.00 & 3.60 & 2.80 & 12.80 & 8.10 & 20.90 \\
\hline & & (21.39) & $(0.55)$ & $(0.57)$ & (9.34) & (2.56) & (10.10) \\
\hline & NS & 62.00 & 3.80 & 3.60 & 10.50 & 7.20 & 17.70 \\
\hline & & (23.33) & $(0.57)$ & $(0.55)$ & (2.18) & $(2.77)$ & (3.15) \\
\hline \multirow[t]{4}{*}{ Average } & S & 60.50 & 3.65 & 3.13 & 13.68 & 9.38 & 23.05 \\
\hline & & (20.12) & (0.83) & (0.63) & (8.71) & (3.93) & (9.31) \\
\hline & NS & 50.00 & 3.55 & 2.93 & 13.63 & 7.68 & 21.32 \\
\hline & & (24.33) & (1.27) & (0.78) & (7.53) & (5.03) & (9.10) \\
\hline
\end{tabular}

${ }^{1} \mathrm{P}=0.12 ;{ }^{2} \mathrm{P}=0.76 ;{ }^{3} \mathrm{P}=0.37 ;{ }^{4} \mathrm{P}=0.88 ;{ }^{5} \mathrm{P}=0.21 ;{ }^{6} \mathrm{P}=0.58$

\section{Heat tolerance test}

The results for the Heat Tolerance Test for each animal are shown in Table 3, where the bulls are divided into the two experimental groups (S and NS), and the means were 9.77 and 9.70, respectively, for S and NS. Table 3 shows the correlation between the Individual Heat Tolerance Index (IHTI) and the abnormalities of the semen. There were no differences ( $p>0.05$ ) between the bulls' IHTIs, and no significant ( $p>0.05$ ) correlation between the semen abnormalities and the IHTI was observed. 
Table 3. Correlation between Individual Heat Tolerance Index (ITHI) and semen abnormalities with the corresponding P-value.

\begin{tabular}{ccc} 
& \multicolumn{2}{c}{ Individual Heat Tolerance Index } \\
\cline { 2 - 3 } & Correlation & $\mathbf{P}$ \\
\hline Minor defects & 0.22427 & 0.1699 \\
Major defects & 0.09055 & 0.5835 \\
Total defects & 0.19101 & 0.2441 \\
\hline
\end{tabular}

\section{Discussion}

The importance of environmental strategies to reduce animal stress has been discussed jointly regarding animal welfare and the necessity to increase animal production and reproductive characteristics. Currently, it is widely recognized that to maintain a sustainable chain-of-food capable of providing adequate results on special regarding farm animals, the avoidance of heat stress is one essential strategy to be disseminated (Bertoni, 2021; Polsky \& von Keyserlingk, 2017; Roth, 2020).

Particularly in cattle, it has been shown that Bos taurus taurus breeds and crossbreeds are more susceptible to heat stress when farmed in hot climates, whereas environmental strategies in the management of heat stress are not necessarily needed in Bos taurus indicus cattle such as Nelore. Herein we aimed to evaluate the heat tolerance of Brahman bulls, a Bos taurus indicus cattle, in its physiological environment, without artificial induction of scrotal increase of temperature and monitoring the differences in the same season and environment, considering the availability of shadow in the grassland-based systems.

The best indicator of heat stress has been greatly discussed already. For example, T. Mader et al. (2010) showed that BGHI might be a better indicator of heat stress because BGT is susceptible to wind speed because black globe temperature is related to the radiant temperature, to which the animal is susceptible. In addition, BGT has a better correlation to rectal temperature compared to others variables such as dry bulb temperature and wet bulb temperature (Buffington et al., 1981; Dikmen \& Hansen, 2009). In the present study, it was observed that both the BGHI and THI measures are equally reasonable. They vary similarly, however, on a different grade.

According to Zimbelman et al. (2009), in dairy cattle, when the THI reaches 68 , milk production begins to decline. Others authors consider that a THI of 72 is when milk production begins to decrease (Ravagnolo \& Misztal, 2000). Even regarding beef cattle, a THI between 70 and 74 is considered a potential heat stress. According to the same authors, a THI between 74 and 79 is classified as dangerous for livestock health (Mader et al., 2006). In our study, the THIs were above 77, and the lowest THI measured was 70 at night, assuring that the environment was warm enough to cause heat stress. Despite these high THIs, the animals showed no signs of stress while they were at their paddocks. Interestingly, the animals comprising the shade-available experimental group did not remain under the shadow throughout the experiment, and no differences in the behavior of the animals were observed between groups..

Zebu cattle present peculiar characteristics that help them with heat exchange with the environment: (a) light-colored short hairs with a melanin medulla; (b) dark skin color, which is full of melanin; and (c) some skin folds. White-colored hairs reflect all the colors in the visible spectrum, and their length prevents the stagnation of a hot air layer around the animal. The melanin medulla and the dark skin prevent UV penetration. The skin folds increase the animal's surface area for convective heat loss, and there are proportionally more sweat glands (Behl et al., 2010). The scrotal mechanism of holding the testes away from the body also helps maintain the testes' temperature (Carrick \& Setchell, 1977). In addition, zebu cattle have years of adaptation to hot climates and have a compensatory mechanism during the night to deal with the daily heat load. Nonetheless, for Bos taurus taurus Fisher et al. (2008) and C. G. Titto et al. (2011) found differences in the behavior of Simmental bulls and Holstein-Friesan cows when applying similar treatments, as also reported by Blackshaw and Blackshaw (1994). 
The present findings in sperm morphology are similar to those reported by Brito et al. (2004), Koivisto et al. (2009), and Vogler et al. (1993); i.e., no differences between groups were observed, and no differences between different collection time were observed. Such findings were not surprising because the adaptation of Bos taurus indicus to tropical temperatures has already been reported in Nelore bulls (Bao Tarragó et al., 2013a), and therefore, it may infer herein that Brahman bulls might present similar characteristics in this context. The sperm abnormalities found in our study also corroborates the findings of Fernandes et al. (2008) and Teixeira et al. (2011), wherein semen morphology presented similar proportions of abnormalities. Some studies using scrotal insulation showed differences after the insulation, where the testis degenerated, and semen quality decreased (Rahman et al., 2011); however, it may be emphasized that an important difference in the present study is the observation in the summer and at the natural environment.

The scrotal circumference of the bulls in this study was in the normal range for the age and breed. Morris et al. (Morris et al., 1989), in a work with 921 Brahman bulls, related average scrotal circumference of 30.9 and 34.1 to bulls aged 24 and 30 months, respectively. Other studies with older Bos taurus indicus bulls showing similar results (Chacón et al., 2002; Pastore et al., 2008; Wildeus \& Hammond, 1993). As an acute response to testicular degeneration, testes become flaccid. As testicular degeneration progresses and becomes irreversible, the testes become stiffer and reduce in size. In our study, it was not observed, in agreement with other studies using $B$. taurus indicus (Chacón et al., 2002; Nichi et al., 2006), whereas other studies using testicular insulation reported alterations in testicular consistency. Those studies generally report that the testis becomes more flaccid after insulation, an increase of defects; and a decrease of motility. In our study, we simulated what occurs in the bovine natural environment, a grassland-based system. We did not find any significant difference in testicular consistency at the beginning and end of the experiment for all tested bulls, and the findings for testicular consistency are in agreement with the semen analysis.

The Heat Tolerance Test (HTT) was developed to be a practical tool for assessing thermolysis capacity in bovine. Gaughan et al. (1999, 2010), Hammond et al. (1996), and Mader et al. (2010) suggested other methods on evaluating heat tolerance, such as respiration rate, serum cortisol concentration, painting scores, or the use of a climate chamber. Almost all of these methods were used in large-scale experiments (three of four), and although the results are reliable, these methods seem to be more complex and to have similar results to the HTT. In the HTT, the bulls were managed for less than four hours in only three days, where care was taken not to stress the bulls to obtain the most reliable results possible. The tested bulls had an impressive thermolysis capacity, corroborating the data reported by Gaughan et al. (1999) and Hammond et al. (1996). Other studies using the HTT reported average values of 9.33 (Titto et al., 2006, 2011) and 8.78 for Simmental Bulls and higher values than 9.85 in Nellore bulls (Titto et al.,1999). In addition, even though no differences were observed between the groups in our study, there were significant differences between animals. In the group NS, the bulls showed the same heat tolerance as the S group. In addition, all bulls presented high heat tolerance. The overall results of this research are similar to those found by Bao Tarragó et al. (2013b), who evaluated the reproductive characteristics of Nelore bulls subjected to the same treatments.

\section{Conclusions}

The studied Brahman bulls showed high heat tolerance demonstrated by the great values obtained in the Heat Tolerance Test. Shadow availability did not shift the reproductive characteristics evaluated. And, although, Bos taurus indicus shows great adaptability to hot climates, it must be highlighted that environmental strategies are recommended to avoid heat stress in cattle. The next steps should include further information on offspring since such important information has not been thoroughly addressed in farm animals so far.

\section{Acknowledgements}

The authors would like to acknowledge Agropecuária São Leopoldo Mandic for providing the animals and CAPES (Coordination for the Improvement of Higher Education Personnel financial code 001). The study was conducted at Agropecuária São Leopoldo Mandic and at the 
Laboratório de Biometeorologia e Etolgia (LABE) da Faculdade de Zootecnia e Engenharia de Alimentos (FZEA/USP), Campus "Fernando Costa", Pirassununga, SP, Brazil.

\section{Ethics statement}

All procedures were performed following the rules issued by the National Council for Control of Animal Experimentation (CONCEA), following the ARRIVE guidelines, and was approved by the Ethics Committee on Animal Experimentation of the Faculty of Animal Science and Food Engineering, University of São Paulo (Protocol \#4400100621).

\section{Financial support}

PFN and AMOT - Received scholarship from CAPES (Coordenação de Aperfeiçoamento de Pessoal de Nível Superior); ACAPMG, TMCLS, RAV and AFCA - Received scholarship from FAPESP (Fundação de Amparo à Pesquisa do Estado de São Paulo); RPA and EALT - None.

\section{Conflict of interests}

PFN, ACAPMG, TMCLS, RAV, AMOT, AFCA, RPA and EALT - No conflict of interest.

\section{Authors' contributions}

PFN and EALT - Coneptualization. PFN, ACAPMG, TMCLS, RAV and AMOT - Development of methodology; preparation and writing the initial draft. AFCA - Application of statistical study data, Review and Editing manuscript. PFN, AFCA, RPA and EALT - Writing, Review and Editing manuscript. EALT - Supervision.

\section{Availability of complementary results}

The data presented in this study are presented in the article and available on request from the corresponding author.

The study was carried out at Agropecuária São Leopoldo Mandic and at the Laboratório de Biometeorologia e Etolgia (LABE), Faculdade de Zootecnia e Engenharia de Alimentos (FZEA/USP), Campus "Fernando Costa", Pirassununga, SP, Brasil.

\section{References}

Bao Tarragó, O. F., Rodrigues, M. D. P., Zaffalon, F. G., Andrade, A. F. C., Fantinato Neto, P., Alonso, M. A., \& Arruda, R. P. (2013a). Efeitos da disponibilidade de sombra a campo sobre características reprodutivas de touros da raça Nelore (Bos indicus) criados na região Sudeste do Brasil. Brazilian Journal of Veterinary Research and Animal Science, 50(6), 482. http://dx.doi.org/10.11606/issn.1678-4456.v50i6p482-487.

Bao Tarragó, O. F., Rodrigues, M. D. P., Zaffalon, F. G., Andrade, A. F. C., Fantinato Neto, P., Alonso, M. A., \& de Arruda, R. P. (2013b). Efeitos da disponibilidade de sombra a campo sobre características reprodutivas de touros da raça Nelore (Bos indicus) criados na região Sudeste do Brasil. Brazilian Journal of Veterinary Research and Animal Science, 50(6), 482. http://dx.doi.org/10.11606/issn.1678-4456.v50i6p482-487.

BARTH, A.D., OKO, R.J. (Eds.). Abnormal morphology of bovine spermatozoa. Ames: Iowa State University Press, 1989. p.19-88.

Behl, R., Behl, J., \& Joshi, B. K. (2010). Heat tolerance mechanisms in cattle-status in zebu cattle: a review. The Indian Journal of Animal Sciences, 80(9). http://epubs.icar.org.in/ejournal/index.php/IJAnS/article/view/893

Bertoni, G. (2021). Human, Animal and Planet Health for Complete Sustainability. Animals, 11(5), 1301. http:// dx.doi.org/10.3390/ani11051301. PMid:33946569.

Blackshaw, J. K., \& Blackshaw, A. W. (1994). Heat stress in cattle and the effect of shade on production and behaviour: a review. Australian Journal of Experimental Agriculture, 34(2), 285-295. http://dx.doi.org/10.1071/EA9940285.

Blom E. Ultrastrukturen af nogle karakteristiske sperimedefekter og forslag til etnyt klassificerings-system for tyrens sperimiogram [The ultrastructure of some characteristic sperm defects and a proposal for a new classification of the bull spermiogram (author's transl)]. Nordisk Veterinaer Medicin. 1973 Jul-Aug;25(7):383-91. Danish. PMID: 4768226.

Boe-Hansen, G. B., Rêgo, J. P. A., Satake, N., Venus, B., Sadowski, P., Nouwens, A., Li, Y., \& McGowan, M. (2020) Effects of increased scrotal temperature on semen quality and seminal plasma proteins in Brahman bulls. Molecular Reproduction and Development, 87(5), 574-597. http://dx.doi.org/10.1002/mrd.23328. PMid:32083367. 
Brito, L. F. C., Silva, A. E. D. F., Barbosa, R. T., \& Kastelic, J. P. (2004). Testicular thermoregulation in Bos indicus, crossbred and Bos taurus bulls: Relationship with scrotal, testicular vascular cone and testicular morphology, and effects on semen quality and sperm production. Theriogenology, 61(2-3), 511-528. http://dx.doi.org/10.1016/ S0093-691X(03)00231-0. PMid:14662148.

Brown, M. A., \& Brown Junior, A. H. (2002). Relationship of milk yield and quality to preweaning gain of calves from Angus, Brahman and reciprocal-cross cows on different forage systems. Journal of Animal Science, 80(10), 2522-2527. http://dx.doi.org/10.1093/ansci/80.10.2522. PMid:12413073.

Buffington, D. E., Collazo-Arocho, A., Canton, G. H., Pitt, D., Thatcher, W. W., \& Collier, R. J. (1981). Black GlobeHumidity Index (BGHI) as comfort equation for dairy cows. Transactions of the ASAE. American Society of Agricultural Engineers, 24(3), 711-714. http://dx.doi.org/10.13031/2013.34325.

Carrick, F. N., \& Setchell, B. P. (1977). The evolution of the scrotum. In J. H. Calaby \& T. H. Tyndale-Biscoe (Eds.), Reproduction and evolution. Canberra: Australian Academy of Science.

Chacón, J., Perez, E., \& Rodriguez-Martinez, H. (2002). Seasonal variations in testicular consistency, scrotal circumference and spermiogramme parameters of extensively reared Brahman (Bos indicus) bulls in the tropics. Theriogenology, 58(1), 41-50. http://dx.doi.org/10.1016/50093-691X(02)00679-9. PMid:12182363.

Dikmen, S., \& Hansen, P. J. (2009). Is the temperature-humidity index the best indicator of heat stress in lactating dairy cows in a subtropical environment? Journal of Dairy Science, 92(1), 109-116. http://dx.doi.org/10.3168/ jds.2008-1370. PMid:19109269.

Durairajanayagam, D., Agarwal, A., \& Ong, C. (2015). Causes, effects and molecular mechanisms of testicular heat stress. Reproductive Biomedicine Online, 30(1), 14-27. http://dx.doi.org/10.1016/j.rbmo.2014.09.018. PMid:25456164

Façanha, D. A. E., Ferreira, J. B., Morais Leite, J. H. G., de Sousa, J. E. R., Guilhermino, M. M., Costa, W. P., Bermejo Asensio, L. A., de Vasconcelos, A. M., \& Silveira, R. M. F. (2019). The dynamic adaptation of Brazilian Brahman bulls. Journal of Thermal Biology, 81, 128-136. http://dx.doi.org/10.1016/j.jtherbio.2019.02.016. PMid:30975410.

Fernandes, C. E., Dode, M. A. N., Pereira, D., \& Silva, A. E. D. F. (2008). Effects of scrotal insulation in Nellore bulls (Bos taurus indicus) on seminal quality and its relationship with in vitro fertilizing ability. Theriogenology, 70(9), 1560-1568. http://dx.doi.org/10.1016/j.theriogenology.2008.07.005. PMid:18723216.

Fisher, A. D., Roberts, N., Bluett, S. J., Verkerk, G. A., \& Matthews, L. R. (2008). Effects of shade provision on the behaviour, body temperature and milk production of grazing dairy cows during a New Zealand summer. New Zealand Journal of Agricultural Research, 51(2), 99-105. http://dx.doi.org/10.1080/00288230809510439.

Garcia-Oliveros, L. N., de Arruda, R. P., Batissaco, L., Gonzaga, V. H. G., Nogueira, V. J. M., Florez-Rodriguez, S. A., Almeida, F. DOS S., Alves, M. B. R., Pinto, S. C. C., Nichi, M., Losano, J. D. DE A., Kawai, G. K. V., \& Celeghini, E. C. C. (2020). Heat stress effects on bovine sperm cells: a chronological approach to early findings. International Journal of Biometeorology, 64(8), 1367-1378. http://dx.doi.org/10.1007/s00484-020-01917-w. PMid:32388687.

Gaughan, J. B., Bonner, S., Loxton, I., Mader, T. L., Lisle, A., \& Lawrence, R. (2010). Effect of shade on body temperature and performance of feedlot steers. Journal of Animal Science, 88(12), 4056-4067. http://dx.doi. org/10.2527/jas.2010-2987. PMid:20709874.

Gaughan, J. B., Mader, T. L., Holt, S. M., Josey, M. J., \& Rowan, K. J. (1999). Heat tolerance of Boran and Tuli crossbred steers. Journal of Animal Science, 77(9), 2398-2405. http://dx.doi.org/10.2527/1999.7792398x. PMid:10492446.

Godfrey, R. W., Lunstra, D. D., Jenkins, T. G., Berardinelli, J. G., Guthrie, M. J., Neuendorff, D. A., Long, C. R., \& Randel, R. D. (1990). Effect of season and location on semen quality and serum concentrations of luteinizing hormone and testosterone in Brahman and Hereford bulls. Journal of Animal Science, 68(3), 734-749. http:/l dx.doi.org/10.2527/1990.683734x. PMid:2318736.

Hammond, A. C., Olson, T. A., Chase Junior, C. C., Bowers, E. J., Randel, R. D., Murphy, C. N., Vogt, D. W., \& Tewolde, A. (1996). Heat tolerance in two tropically adapted Bos taurus breeds, Senepol and Romosinuano, compared with Brahman, Angus, and Hereford cattle in Florida. Journal of Animal Science, 74(2), 295-303. http://dx.doi. org/10.2527/1996.7422295x. PMid:8690664.

Her, E., Wolfenson, D., Flamenbaum, I., Folman, Y., Kaim, M., \& Berman, A. (1988). Thermal, productive, and reproductive responses of high yielding cows exposed to short-term cooling in summer. Journal of Dairy Science, 71(4), 1085-1092. http://dx.doi.org/10.3168/jds.S0022-0302(88)79656-3. PMid:3392302.

Kastelic, J. P. (2014). Understanding and evaluating bovine testes. Theriogenology, 81(1), 18-23. http://dx.doi. org/10.1016/j.theriogenology.2013.09.001. PMid:24274406.

Kastelic, J. P., Cook, R. B., \& Coulter, G. H. (1997). Scrotal/testicular thermoregulation and the effects of increased testicular temperature in the bull. The Veterinary Clinics of North America. Food Animal Practice, 13(2), 271282. http://dx.doi.org/10.1016/S0749-0720(15)30340-6. PMid:9216048.

Koivisto, M. B., Costa, M. T. A., Perri, S. H. V., \& Vicente, W. R. R. (2009). The effect of season on semen characteristics and freezability in Bos indicus and Bos taurus bulls in the southeastern region of Brazil. Reproduction in Domestic Animals, 44(4), 587-592. http://dx.doi.org/10.1111/j.1439-0531.2008.01023.x. PMid:19090817.

Krininger III, C. E., Block, J., Al-Katanani, Y. M., Rivera, R. M., Chase Junior, C. C., \& Hansen, P. J. (2003). Differences between Brahman and Holstein cows in response to estrus synchronization, superovulation and resistance of embryos to heat shock. Animal Reproduction Science, 78(1-2), 13-24. http://dx.doi.org/10.1016/s03784320(03)00045-9. PMid:12753779. 
Li, Z., Li, Y., Ren, Y., \& Li, C. (2020). High ambient temperature disrupted the circadian rhythm of reproductive hormones and changed the testicular expression of steroidogenesis genes and clock genes in male mice. Molecular and Cellular Endocrinology, 500,110639. http://dx.doi.org/10.1016/j.mce.2019.110639. PMid:31705921.

Mader, T. L., Davis, M. S., \& Brown-Brandl, T. (2006). Environmental factors influencing heat stress in feedlot cattle. Journal of Animal Science, 84(3), 712-719. http://dx.doi.org/10.2527/2006.843712x. PMid:16478964.

Mader, T., Gaughan, J., Johnson, L., \& Hahn, G. (2010). Tympanic temperature in confined beef cattle exposed to excessive heat load. International Journal of Biometeorology, 54(6), 629-635. http://dx.doi.org/10.1007/ s00484-009-0229-0. PMid:19404683.

McManus, C., Prescott, E., Paludo, G. R., Bianchini, E., Louvandini, H., \& Mariante, A. S. (2009). Heat tolerance in naturalized Brazilian cattle breeds. Livestock Science, 12O(3), 256-264. http://dx.doi.org/10.1016/j.livsci.2008.07.014.

Morrell, J. M. (2020). Heat stress and bull fertility. Theriogenology, 153, 62-67. http://dx.doi.org/10.1016/j. theriogenology.2020.05.014. PMid:32442741.

Morris, D. L., Tyner, C. L., Morris, P. G., Forgason, R. L., Forgason, J. L., Williams, J. S., \& Young, M. F. (1989). Correlation of scrotal circumference and age in American Brahman Bulls. Theriogenology, 31(2), 489-494. http://dx.doi. org/10.1016/0093-691X(89)90553-0. PMid:16726567.

Muller, C. J. C., Botha, J. A., Coetzer, W. A., \& Smith, W. A. (1994). Effect of Shade on Various Parameters of Friesian Cows in a Mediterranean Climate in South-Africa. 2. Physiological-Responses. South African Journal of Animal Science-Suid-Afrikaanse Tydskrif Vir Veekunde, 24(2), 56-60.

Neidhardt, R., Plasse, D., Weniger, J. H., Verde, O., Beltran, J., \& Benavides, A. (1979). Milk Yield of Brahman Cows in a Tropical Beef Production System. Journal of Animal Science, 48(1), 1-6. http://dx.doi.org/10.2527/jas1979.4811.

Newton, L. D., Kastelic, J. P., Wong, B., Van Der Hoorn, F., \& Thundathil, J. (2009). Elevated testicular temperature modulates expression patterns of sperm proteins in Holstein bulls. Molecular Reproduction and Development, 76(1), 109-118. http://dx.doi.org/10.1002/mrd.20934. PMid:18459118.

Nichi, M., Bols, P. E., Zuge, R. M., Barnabe, V. H., Goovaerts, I. G., Barnabe, R. C., \& Cortada, C. N. (2006). Seasonal variation in semen quality in Bos indicus and Bos taurus bulls raised under tropical conditions. Theriogenology, 66(4), 822-828. http://dx.doi.org/10.1016/j.theriogenology.2006.01.056. PMid:16529802.

Pastore, A. A., Toniollo, G. H., Lobo, R. B., Fernandes, M. B., Vozzi, P. A., Vila, R. A., Galerani, M. A. V., Elias, F. P., \& Cardilli, D. J. (2008). Características biométricas, testiculares, seminais e parâmetros genéticos de touros pertencentes ao programa de melhoramento genético da raça Nelore. Ars Veterinária, 24(2), 134-141. http:// www.arsveterinaria.org.br/index.php/ars/article/view/183

Peña Junior, S. T., Stone, F., Gummow, B., Parker, A. J., \& Paris, D. B. B. P. (2021). Susceptibility of boar spermatozoa to heat stress using in vivo and in vitro experimental models. Tropical Animal Health and Production, 53(1), 97. http://dx.doi.org/10.1007/s11250-020-02516-y. PMid:33415455.

Polsky, L., \& von Keyserlingk, M. A. G. (2017). Invited review: Effects of heat stress on dairy cattle welfare. Journal of Dairy Science, 100(11), 8645-8657. http://dx.doi.org/10.3168/jds.2017-12651. PMid:28918147.

Rahman, M. B., Vandaele, L., Rijsselaere, T., Maes, D., Hoogewijs, M., Frijters, A., Noordman, J., Granados, A., Dernelle, E., Shamsuddin, M., Parrish, J. J., \& Van Soom, A. (2011). Scrotal insulation and its relationship to abnormal morphology, chromatin protamination and nuclear shape of spermatozoa in Holstein-Friesian and Belgian Blue bulls. Theriogenology, 76(7), 1246-1257. http://dx.doi.org/10.1016/j.theriogenology.2011.05.031. PMid:21777969.

Rasooli, A., Taha Jalali, M., Nouri, M., Mohammadian, B., \& Barati, F. (2010). Effects of chronic heat stress on testicular structures, serum testosterone and cortisol concentrations in developing lambs. Animal Reproduction Science, 117(1-2), 55-59. http://dx.doi.org/10.1016/j.anireprosci.2009.03.012. PMid:19428197.

Ravagnolo, O., \& Misztal, I. (2000). Genetic component of heat stress in dairy cattle, parameter estimation. Journal of Dairy Science, 83(9), 2126-2130. http://dx.doi.org/10.3168/jds.S0022-0302(00)75095-8. PMid:11003247.

Ribeiro, A. R., Alencar, M., Freitas, A., Regitano, L. C., Oliveira, M. C., \& Ibelli, A. M. (2010). Heat tolerance of Nelore, Senepol x Nelore and Angus x Nelore heifers in the southeast region of Brazil. South African Journal of Animal Science, 39(1). http://dx.doi.org/10.4314/sajas.v39i1.61261.

Rizzoto, G., Boe-Hansen, G., Klein, C., Thundathil, J. C., \& Kastelic, J. P. (2020). Acute mild heat stress alters gene expression in testes and reduces sperm quality in mice. Theriogenology, 158, 375-381. http://dx.doi.org/10.1016/j. theriogenology.2020.10.002. PMid:33038823.

Roth, Z. (2020). Reproductive physiology and endocrinology responses of cows exposed to environmental heat stress - Experiences from the past and lessons for the present. Theriogenology, 155, 150-156. http://dx.doi. org/10.1016/j.theriogenology.2020.05.040.

SAS Institute. (1995). User's guide: basic and statistic. Cary: SAS Institute Inc.

Seifi-Jamadi, A., Zhandi, M., Kohram, H., Luceño, N. L., Leemans, B., Henrotte, E., Latour, C., Demeyere, K., Meyer, E., \& Van Soom, A. (2020). Influence of seasonal differences on semen quality and subsequent embryo development of Belgian Blue bulls. Theriogenology, 158, 8-17.http://dx.doi.org/10.1016/j.theriogenology.2020.08.037. PMid:32916520.

Tatman, S. R., Neuendorff, D. A., Wilson, T. W., \& Randel, R. D. (2004). Influence of season of birth on growth and reproductive development of Brahman bulls. Theriogenology, 62(1-2), 93-102. http://dx.doi.org/10.1016/j. theriogenology.2003.07.027. PMid:15159104. 
Teixeira, H. C. A., Nascimento, N. V., McManus, C., Egito, A. A., Mariante, A. S., \& Ramos, A. F. (2011). Seasonal influence on semen traits and freezability from locally adapted Curraleiro bulls. Animal Reproduction Science, 125(1-4), 56-61. http://dx.doi.org/10.1016/j.anireprosci.2011.04.002. PMid:21550189.

Titto, C. G., Titto, E. A. L., Titto, R. M., \& Mourão, G. B. (2011). Heat tolerance and the effects of shade on the behavior of Simmental bulls on pasture. Animal Science Journal, 82(4), 591-600. http://dx.doi.org/10.1111/j.17400929.2011.00872.x. PMid:21794020.

Titto, C. G., Titto, E. A. L., Vieira, R. V., Glaser, F. D., Titto, R. M., Ablas, D. DE S., Pereira, A. M. F., Leme, T. M. DA C., Gatto, E. G., \& Raineri, C. (2006). Heat tolerance in european beef cattle breeds used for cross-breeding in Brazil. In IV Brazilian Biometeorology Congress (pp. 125-129). Jaboticabal: SBBiomet.

Titto, E. A. L., Pereira, A. M. F., Passini, R., Balierio Neto, G., Fagundes, A. C. A., Lima, C. G., Guimaraes, C. M. C., \& Ablas, D. S. (1999). Heat tolerance study in Marchigiana, Nellore and Simmental young bulls. In IX Congresso de Zootecnia. Porto: APEZ.

Titto, E. A. L., Velloso, L., Zanetti, M. A., Cresta, A., Toledo, L. R. A., \& Martins, J. H. (1998). Teste de tolerância ao calor em novilhos Nelore e Marchigiana. Revista Portuguesa de Zootecnia, 5(1), 67-70.

Tucker, C. B., Rogers, A. R., \& Schutz, K. E. (2008). Effect of solar radiation on dairy cattle behaviour, use of shade and body temperature in a pasture-based system. Applied Animal Behaviour Science,109(2-4), 141-154. http:/l dx.doi.org/10.1016/j.applanim.2007.03.015.

Vogler, C. J., Bame, J. H., DeJarnette, J. M., McGilliard, M. L., \& Saacke, R. G. (1993). Effects of elevated testicular temperature on morphology characteristics of ejaculated spermatozoa in the bovine. Theriogenology, 40(6), 1207-1219. http://dx.doi.org/10.1016/0093-691X(93)90291-C.

Wan, X., He, X., Liu, Q., Duan, P., \& Li, H. (2020a). Frequent and mild scrotal heat stress impairs embryo development, implantation and offspring sex ratio in mice. Reproductive Biomedicine Online, 40(5), 617-626. http://dx.doi. org/10.1016/i.rbmo.2020.01.020. PMid:32276888.

Wan, X., He, X., Liu, Q., Wang, X., Ding, X., \& Li, H. (2O2Ob). Frequent and mild scrotal heat stress in mice epigenetically alters glucose metabolism in the male offspring. American Journal of Physiology. Endocrinology and Metabolism, 319(2), E291-E304. http://dx.doi.org/10.1152/ajpendo.00038.2020. PMid:32603600.

Wildeus, S., \& Hammond, A. C. (1993). Testicular, semen and blood parameters in adapted and nonadapted Bos-Taurus bulls in the semiarid tropics. Theriogenology, 40(2), 345-355. http://dx.doi.org/10.1016/0093691X(93)90272-7. PMid:16727320.

Zimbelman, R. B., Rhoads, R. P., Rhoads, M. L., Duff, G. C., Baumgard, L. H., \& Collier, R. J. (2009). A re-evaluation of the impact of Temperature Humidity Index (THI) and Black Globe Humidity Index (BGHI) on milk production in high producing dairy cows. In 24th Annual Southwest Nutrition and Management Conference (pp. 158-159). Arizona: The University of Arizona. 